City University of New York (CUNY)

CUNY Academic Works

\title{
LEVERAGING THE POPULARITY OF VIRTUAL CONFERENCING DUE TO THE COVID-19 PANDEMIC TO CREATE NEW OPPORTUNITIES FOR STEM EDUCATION
}

\author{
Andrew Singh \\ cUNY York College \\ Nazrul I. Khandaker \\ cUNY York College \\ Violeta Escandon Correa \\ Georgia Institute of Technology \\ Omadevi Singh \\ cUNY York College \\ Ariel Skobelsky \\ Francis Lewis High School
}

See next page for additional authors

\section{How does access to this work benefit you? Let us know!}

More information about this work at: https://academicworks.cuny.edu/yc_pubs/300

Discover additional works at: https://academicworks.cuny.edu

This work is made publicly available by the City University of New York (CUNY).

Contact: AcademicWorks@cuny.edu 


\section{Authors}

Andrew Singh, Nazrul I. Khandaker, Violeta Escandon Correa, Omadevi Singh, Ariel Skobelsky, Farhan Tanvir, Brian Sukhnandan, Matthew Khargie, Elton Selby, and Masud Ahmed 


\section{LEVERAGING THE POPULARITY OF VIRTUAL CONFERENCING DUE TO THE COVID-19 PANDEMIC TO CREATE NEW OPPORTUNITIES FOR STEM EDUCATION} NASA

SINGH, Andrew, Earth and Physical Sciences, York College of CUNY, 9420 Guy R Brewer BIvd, AC-2F09, Jamaica, NY 11451-0001, KHANDAKER, Nazrul, York College of CUNY, 9420 Guy R Brewer BIvd, AC-2F09, Jamaica, NY 11451-0001, CORREA, Violeta Escandon, Georgia Institute of Technology, North Ave NW, Atlanta, GA 30332, SINGH, Omadevi, NASA MUREP AEROSPACE ACADEMY, York College - City University of New York, 94-20 Guy R. Brewer Blvd., Jamaica, NY 11451, SKOBELSKY, Ariel, Francis Lewis High School, 58-20 Utopia Pkwy,, Queens, NY 11365, TANVIR, Farhan, Bronx High School for the Sciences, 75 W 205th St, Bronx, NY 10468, SUKHNANDAN, Brian, Queens College, 65-30 Kissena Blvd, Flushing, NY 11367, KHARGIE, Matthew, CoEnterprise, 45 West, 36TH Street, New York City, NY 10018, SELBY, Elton, SUNY Buffalo State College, 1300 Elmwood Avenue, Buffalo, NY 14222 and AHMED, Masud, New York City Department of Environmental Protection, Geotechnical Section, NYCDEP, 59-17, Junction Blvd, Queens, New York, NY 11373
INTRODUCTION

Due to the COVID-19 pandemic, virtual learning has become a necessity for K9-16 education. Virtual classwork has been administered through plattorms such as Google Classroom, Clever, and iReady.

During the summer of 2021, the City University of New York (C.U.N.Y) York College campus hosted its NASA MAA MUREP (Minority University Research and Education Project Aerospace Academy) program virtually using a combination of Zoom, Google Docs, and even Canva, which some stude
requested as a more intuitive alternative to Microsoft requested as an
PowerPoint.

\section{PEER MENTORING INITIATIVES}

Students were mentored to use the scientific method to explore their interests in the STEM field, with a geoscience or environmental science focus where possible. Students were trained to:

1) obtain peer reviewed articles from reputable sources such as Springer and Google Scholar

2) locate reputable raw datasets from sources such as the EPA, NASA, NOAA, NIH, AMS, USGS, census.gov and many others

3) analyze and discuss such data with a hypothesis in mind and represent the data in graphical form using Microsoft Exce and PowerPoint

4) ultimately form a conclusion based on the hypothesis.

\section{DATA RETREIVAL TRAINING}

Since many government bodies and reputable scientific teams worldwide conduct extensive sampling and data collection (while making this data publicly available), this virtual education approach allows the exploration of STEM topics without necessitating field or laboratory sampling.

Availability of open access information pertaining to benchmark publications through the internet, it has opened a plethora of opportunities for more scientific research.

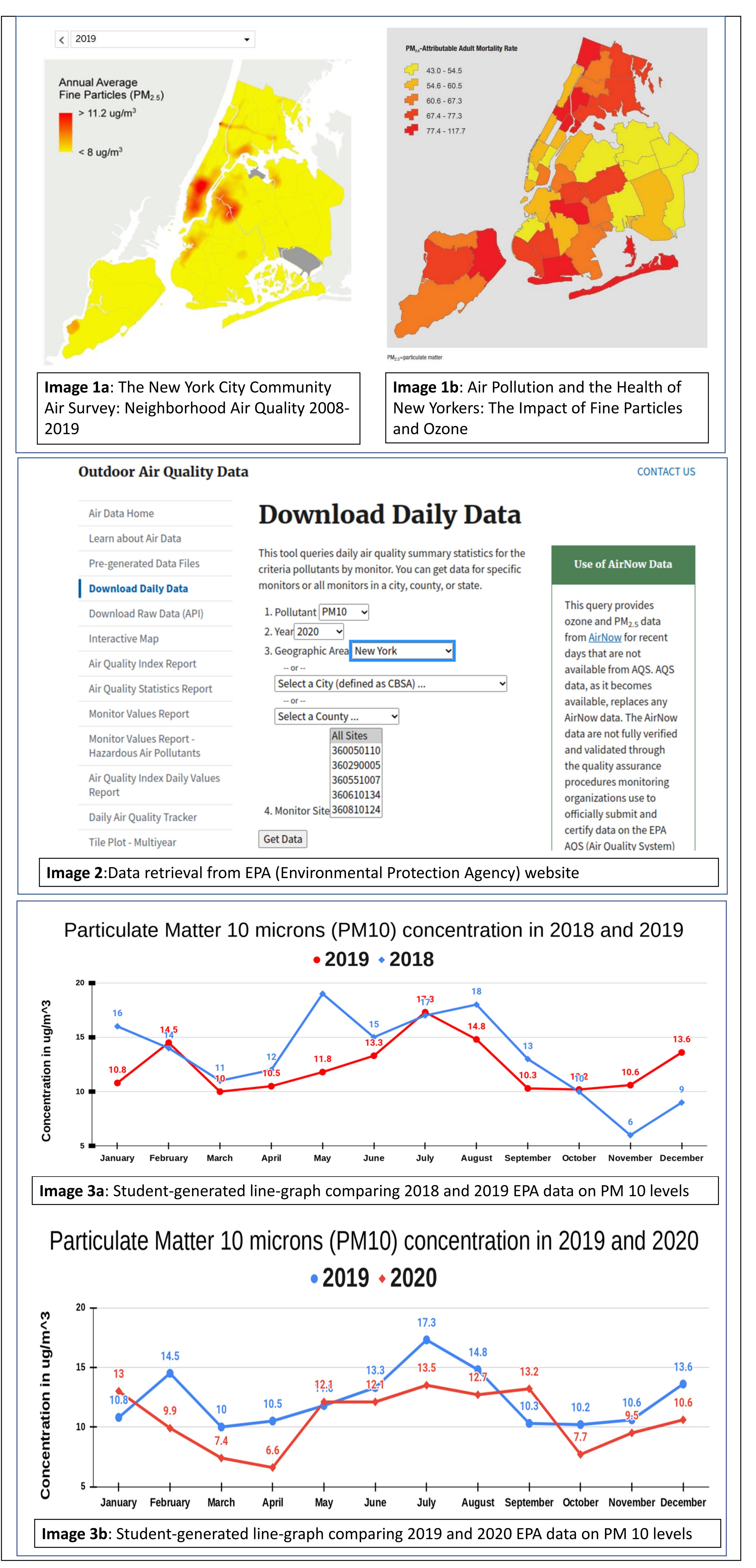

TOPIC SELECTIONS AND STUDENTS CENTERED RESEARCH

The innovative combination of virtual learning tools along with email communications, allowed students to meet for hours sessions muliple times a week and receive posters to present their work.

Topics included: the effects of air pollution on respiratory health, acid rain in the northeastern United States, and particulate matter (10 microns) pollution in New York state in 2019 and 2020.

POSITIVE OUTCOME DUE TO MULTIPLE CUMMUNICATION APPROACHES

The virtual platforms also enabled students to share their work-in-progress for feedback from peers, as well as allowed the students to use other forms of communication such as chat instead of only voice-communication or only face-to-face interaction.

This flexibility gave an additional level of confidence to the participating students.

\section{ACKNOWLEDGEMENTS}

The authors greatly acknowledges the research opportunity provided by The City University of New York (CUNY) - York College \& NASA MAA MUREP (Minority University Research and Education Project Aerospace Academy) 2021 Program. Funding from AT\&T and ConEdison greatly helped to support high school students peer mentoring and research experience during the global COVID-19 pandemic.

\section{ABSTRACT}

Geological Society of America Abstracts with Programs. Vol 53, No. 6, 2021

doi: 10.1130/abs/2021AM-367187 